\title{
The Influence of Publicity and Sales Promotion on Marketing Performance in Nigeria
}

\author{
By Michael Segun Ogunmuyiwa*
}

\begin{abstract}
Sales promotion and publicity are key promotional marketing tools which have assisted organizations to wax stronger in a global competitive environment. This study investigates the significance of publicity and sales promotion in Nigeria. The research design adopted for this study is survey research design while the sampling technique adopted is simple random sampling technique The Chi-square method is used to test the hypothesis based on the responses from the five-point Likert rating scale of the structured questionnaire. The findings reveal that publicity and sales promotion are veritable tools for achieving organizational marketing goals in a competitive marketing environment. It is recommended that publicity and sales promotion should be well utilized to stimulate customers demand, boost organizational reputation without detriment to product quality and performance.
\end{abstract}

JEL Codes: $M 31$, M37

Keywords: publicity, sales promotion, digital marketing era, promotion mix, marketing tools, marketing performance

\section{Introduction}

In today's digital marketing era marked by intense technological revolution and increasing global competition, there is an increasing demand for innovative approach of stimulating sales and patronage for the company's products and services. Pembi et al. (2017) described that the marketing communication mix elements have become important players in the life of any businesses be it small, medium or large. They foster the movement of market offerings (goods, services and ideas) from producers to consumers and assists in building relationships with customers and other stakeholders of the company. Promotion is used as a tool to gain the support of the trade, either directly through trade promotion or indirectly through consumer promotion (Akanbi and Ajagbe 2012). This has largely necessitated the pronounced use of sales promotion as a promotion tool to increase customers demand and patronage, stimulate trial purchase, create brand switching and market share (sales revenue) in many competitive industries (Preko 2012).

Sale promotion are any intermittent and/or a short term incentives designed to encourage purchase or sale of product or service usually but not always personal in nature and usually non media base (Dzansi 2016). The study conducted by Oyedapo et al. (2012) revealed that sales promotion consists of the related promotional activities that are necessary to supplement personal selling. The scholars emphasized that sales promotion emerged as a reaction by manufacturers,

"Senior Lecturer, Department of Business Administration, Olabisi Onabanjo University, Nigeria. 
marketers and salesmen alike to find a short term solution to the problems of excess stock of goods which are available in manufacturer's warehouses but are not demanded by consumers and organizations.

Olawore (2013) asserted that there is a growing significance of sales promotion due to appreciable interest in the impact of sales promotion on different dimension such as brand perception, brand switching behaviour, brand choice, evaluation of brand equity and consumer decision process. Chaharsoughi and Yasory (2012) succinctly affirmed that sales promotions is a range of marketing techniques designed within a strategic marketing framework to add extra value to a product or service over and above the "normal" offering in order to achieve specific sales and marketing objectives. This extra value may be a short term tactical nature or it may be part of a longer-term franchise-building program. Sales Promotion is a short term incentive to encourage purchase or sales of a product or service. It includes those marketing activities, other than personal selling, advertising and publicity, which stimulate consumers purchasing and dealers' effectiveness such as window display, shows, expositions, demonstrations, etc., (Jain 2014).

Sales promotion is also concerned with the creation, application and dissemination of materials and techniques that supplement advertising and personal selling (Preko 2012, Salaam 2017). Moreover, Tandoh and Sarpong (2015) described sales promotions as a short term promotional activities designed to stimulate consumer buying or co-operation from distributors, sales agents, or other members of the trade.

All organizations operate in diverse public spheres and create new publicity with their actions to build public trust and reputation. Tufail et al. (2014) contended that publicity is one of the best management functions that establishes, recognizes and assists in maintaining reciprocal and mutually benefiting relationship with the public. Publicity is the distribution of information by personal or non-personal ways, which is not directly rewarded for by the company, nor is the company the source (Salaam 2017). He stressed further that publicity has a resounding and positive effects on brand equity and position institutions and their products in the consumer's mind which is influencing the desirable and effective marketing performance. Publicity is the movement of information with the effect of increasing public awareness of a subject. Technology has revolutionized business activities across the globe and has resulted to intense local and international competition which resulted into brand switching, declining marketing performance and decreasing market share which hinder the realization of firm marketing objectives (Pandey and Singh 2017, Zeng 2013).

Previous empirical study and extant literatures reviewed (Oyeniyi 2011, Pandey and Singh 2017, Pembi et al. 2017) failed to capture the significance of publicity and sales promotion on firm marketing objectives. Therefore, this study intends to fill the identified gap by examining the influence of publicity and sales promotion on marketing performance in the new digital marketing era using Nigerian Breweries PLC as a case study. This paper is structured in the following format. After the introduction; section two centers on the concepts of publicity, sales promotion and theoretical framework. Section three focuses on the 
methodology and section four is the empirical results and discussion, while section five discusses the conclusion and policy recommendations.

\section{Theoretical Background and Literature Review}

\section{Publicity and Marketing Performance}

The concept of public relations is a very important promotion tool for business organizations because positive relations built with the public can directly and indirectly affect the business organization activities. Public relations is the process of "building good relations with the firm's various publics by obtaining favourable publicity, building up a good corporate image, and handling off unfavorable rumors, events and stories" (Bernays 1955).

Brassington and Pettit (2000) also posited that the essence of public relations (PR) is to look after the nature and quality of the relationship between the organization and its different publics, and to create a mutual understanding. Public relations cover a range of activities, for example the creation and maintenance of corporate identity and image; charitable involvement, such as sponsorship, and community initiatives; media relation for the spreading of good news as well as for crisis management. Alli (2010) succinctly affirmed that publicity is an instrument used by firms to neither disseminate information about itself through mass media but does not pay for exposure. It is geared towards increasing the company image and popularity. Publicity is the process of building good relations with the firm's various publics by obtaining favorable publicity, building up a good corporate image, and handling or heading off unfavorable rumors, stories, and events (Alli 2010, Pandey and Singh 2017). Publicity, as a social system, is never totally predictable, and a small change at one point in time may generate disproportionate social change later (Aula and Aberg 2013). Publicity is a dynamic process in which issues arise, may reach the tipping point, or fade away (Evgeny 2011).

Publicity is described as any unpaid broadcasting or publishing about positive or negative news of the company, or its products and activities by using mass media (Nour et al. 2014). Similarly, Kotler and Keller (2006) saw publicity as one of the key pillars for an organization success regardless of the size and age. It aids self-image and promotion of personality (Alli 2010, Zeng 2013). Positive publicity results to increased trust and high expectations (Tarlow 2011). Publicity as defined by Aremu and Lawal (2012) is regarded as news about the organization or its product reported in the press and other media without charge to the organization. It has provided a platform for organizations to raise awareness among stakeholders and encourage their participation, change people's thinking and behavior in relation to a particular organization and product, informing people about the organization and product and its achievements and any changes in regulations or management activities and raising awareness at regional and International levels to strengthen linkages (Aula and Åberg 2013, Evgeny 2011, Oyedapo et al. 2012). 
Gbolagade et al. (2013) conducted a study on the impact of marketing strategy on business performance a study of selected Small and Medium Enterprises (SMEs) in Oluyole local government, Ibadan, Nigeria. The survey research design method was used in this study which involves using a self-design close-ended questionnaire in collecting data from one hundred and three (103) respondents. Correlation coefficient and multiple regression analysis were used to analyze the data. The results showed that the independent variables (i.e Product, Promotion, Place, Price, Packaging and After sales service) were significant joint predictors of business performance in term of profitability, market share, return on investment, and expansion.

In a study conducted by Mohammed and Adamkolo (2018) on public relations and employee performance in Nigerian tertiary institutions affirmed that effective public relations practice that addresses both the comprehensive and specific needs of the various classifications of internal publics enhances job performance and productivity.

\section{Sales Promotions and Marketing Performance}

Sales promotion is the process of persuading a potential customer to buy the product. It is designed to be used as a short term tactic to boost sales. Sales promotion is a marketing tool for manufacturers as well as for retailers. The manufacturers normally use the promotional strategy to increase sales to retailers in form of trade promotions and consumers in form of consumer's promotions. Sales promotions are vital for companies to increase sales and project their brand names. If used moderately with careful planning, sales promotion increases sales, even after the promotions period is completed. When sales promotion is overdosed, the emotion that surrounds them disappears. Oyedapo et al. (2012) posited that sales promotion is a direct inducement that offers an extra value or incentive for the product to the sales force, distributors or the ultimate consumer with the primary objective of creating an immediate sale. The purpose of sales promotion is to motivate the customers to immediately purchase a particular product thus enhancing its sales volume (Sadia and Syeda 2012). Sales promotion campaign is often the only promotional material available at the point of purchases which inform, remind and also stimulate the buyers (Daramola et al. 2014).

Odunlami and Ogunsiji (2011) said that sales promotion is an initiative undertaken by organizations to promote increase in sales, usage or trial of a product or service (i.e., initiations that are not covered by other elements of the marketing communication/ promotional mix). Sales promotion is defined as a diverse collection of incentive tools, mostly, short term designed to stimulate quicker and/or greater purchase of particular products/services by consumers (Sadia and Syeda 2012). Bagavathi-Pillai (2007) stated that sales promotion refers to those promotions selling that stimulate interest, trial or purchase by final customers or others in the channel.

Sales promotion is therefore an incentive marketing tool in that it helps to increase repeat purchase, contributes to both short and long term sales increase of 
a product or service and contributes to the utilization values of advertising in that many advertising programmes are undertaken to support the firm's promotional activities (Ekankumo and Henry 2011). Sales promotion is an important component of an organizations overall marketing strategy along with advertising, public relations, and personal selling. Sale promotion acts as a competitive weapon by providing an extra incentive for the target audience to purchase or support one brand over another (Oladele 2006). Accordingly, Preko (2012) argued that sales promotions are all other promotional tools that are classified as advertising, personal selling or publicity. It includes consumer promotion (samples, coupons, money refund offers, trading stamps, demonstrations) and trade promotion (e.g., buying allowances, free goods, merchandise allowances, dealer's sales contest) and sales force promotion (e.g., bonuses and sales rallies). Onu (2000) cited in Daramola et al. (2014) opined that sales promotion are those marketing activities other than personal selling, advertising and publicity that arouse consumers' purchases and dealer efficacy such as display shows, and exhibition, demonstrations and various non-current selling efforts not in the ordinary routine.

Nadeem et al. (2013) carried out a study on the role of sales promotion on sales volume in the context of fast moving consuming goods industry in Dera Ghazi Khan. The study adopted a survey research design using structured questionnaire to collect information from 120 respondents. The result shows that all sales promotion dimensions independently and jointly predict sales volume, which implies that premiums, bonus, have significant effect on sales volume. Moreover, sales promotion tends to work best when it is applied to impulse items whose features can be judged at the point of purchase, rather than more complex, expensive items that might require hands on demonstration. Sales promotion includes communication activities that provide extra value or incentives to ultimate consumers, wholesalers, retailers or other organizational customers. It also stimulates sales, and product trial (Boone and Kurtz 2002). Sales promotion when implemented effectively often results in an increase in short term sales returns. This explains the inclination of corporations to put in a large percentage of their funds in carrying out various sales promotion activities. However, variations occur in effects of sales promotion based on the attractiveness of the concerned brand (Sadia and Syeda 2012).

Musibau et al. (2014) posited in their study on the impact of sales promotion and product branding on company performance in Nigeria posited that product branding and sales promotion affect organizational growth. Also, Onyejiaku et al. (2018) in a paper titled does promotional strategy affect the growth of manufacturing firms in South East Nigeria using a both Speraman's rank correlation and logistic regression on both primary and secondary data affirmed that advertising, public relations and personal selling were promotional strategies that affected sales growth in the manufacturing firms. The study also revealed that promotional strategy had a positive and significant effect on sales growth.

Mbogo (2013) carried out a study on the influence of promotion mix strategies on the growth of customers of Pathologists Lancet Kenya. The study adopted a descriptive research design and the target population was clustered into 4 regions in Nairobi (Nairobi East, West North and South) on Pathologists 
Lancet Kenya's customers. Forty customers were sampled and semi-structure questionnaire administered. Pearson correlation and multiple linear regression analysis were done to test the relationship between promotion and customer growth. The findings revealed that Pathologists Lancet Kenya as a brand is associated with product quality and cheap price that both adds value and satisfaction to its customers. The study revealed that promotion strategies (advertising, sales promotion, public relations, personal selling and direct marketing) positively influence customer growth.

Festus (2016) conducted a research on the impact of sales promotion on organizational performance of Guinness Ghana Breweries Limited. The study adopted a descriptive research design. The population of the study was estimated at 865 (management, staff and key distributors) out of which a sample of 160 was used Questionnaire was used to collect primary data whilst secondary data was taken from financial statements of GGBL from 1985 to 2014. The study found a positive and significant relationship between sales promotion and profitability.

\section{Theoretical Framework}

The theoretical underpinnings for this study are Planned Behaviour Theory and Combination Theory. The Planned Behaviour Theory emphasized that behaviour may be modified by sales promotion stimuli, which change beliefs, attitudes and eventually intentions and behaviour. If the intervention influences customers, it changes intentions and eventually changes the behaviour. While the Combination Theory embrace the use of Push and Pull strategies. "Push" is used to get more products into the hands of retailers and wholesalers while sales promotion dimensions and product tie-ins with other products are used as a "pull" to get more people to want to buy the product.

\section{Research Methods and Procedure}

The study employed a survey research design of the descriptive type and data were gathered using the primary data method. The research instrument used is the questionnaire and the sample size is purposively selected from a population of one hundred and five (105) sales and marketing staff in Nigerian Breweries PLC in Lagos and Ota plants of the company. Purposive sampling was used to select two (2) out of the several plants of Nigerian Breweries PLC in Nigeria. The plants were chosen because of nearness and convenience to administer the questionnaire. In addition, the management style of Nigerian Breweries is similar in all the plants.

Out of a total population of 105, sixty (60) sales and marketing officers were selected. Thirty (30) copies each of the structured questionnaire on a five point Likert rating scale were administered on the sales and marketing staff of both Ota and Lagos breweries. Twenty-seven (27) out of the 30 questionnaire in Ota and Twenty-eight (28) out of the 30 in Lagos were duly filled and returned. From these, fifty (50) copies of the questionnaire representing Twenty-five (25) from 
each plant were finally made use of and this is the final sample size for this study. Data were analyzed using simple percentage and Chi-square statistical tool.

\section{Reliability/Validity of the Research Instrument}

In determining the reliability of this instrument, the researcher utilized test-retest reliability method instead of Multiple, Split-half and Cronbach alpha methods because it is easy to understand, applied and also facilitate easy interpretations of the reliability test. Pilot reliability test of (10 students) was carried out before administering the real research questionnaires. In the preceding week, we readministered another 10 copies of the questionnaire to ascertain whether the results obtained in the first pretest and piloted study agreed with the second pilot/test-re-test research.

It was discovered that there was similarity in the results obtained. This shows high degree of reliability of the research instrument used since over $78 \%$ of reliability was obtained because the responses obtained in the first and second test and retest reliability study was similar. The instrument was subjected to both face and content validity. The drafted questionnaire was given to two (2) professors and two (2) senior lecturers in our department for evaluation and correction. Based on the identified mistakes, necessary corrections were done to ensure that the research instrument is valid.

\section{Results and Discussion}

Question by Question Analysis

Table 1. Publicity and Sales Promotion Enhance Achievement of Organizational Marketing Objectives

\begin{tabular}{|l|c|c|}
\hline & Frequency & Percentage (\%) \\
\hline Strongly agreed & 44 & 88 \\
\hline Agreed & 5 & 10 \\
\hline Undecided & 1 & 2 \\
\hline Disagree & 0 & 0 \\
\hline Strongly disagreed & 0 & 0 \\
\hline Total & 50 & $100 \%$ \\
\hline
\end{tabular}

Table 1 indicates that $88 \%$ of the respondents indicating strongly agreed, $10 \%$ agreed, $2 \%$ was undecided; zero respondent disagreed and strongly disagree. This shows that publicity and sales promotion enhance achievement of organizational marketing objectives. 
Table 2. Publicity and Sales Promotion Increase Sales Returns

\begin{tabular}{|l|c|c|}
\hline & Frequency & Percentage (\%) \\
\hline Strongly Agreed & 40 & 80 \\
\hline Agreed & 5 & 10 \\
\hline Undecided & 2 & 4 \\
\hline Disagreed & 3 & 6 \\
\hline Strongly disagreed & 0 & 0 \\
\hline Total & 50 & $100 \%$ \\
\hline
\end{tabular}

Table 2 shows that $80 \%$ strongly agreed, $10 \%$ agreed, $4 \%$ undecided, $6 \%$ disagreed, while $0 \%$ strongly disagreed. This indicates that publicity and sales promotion increase sales returns.

Table 3. Publicity as a Promotional Tool Promotes Reputation of the Organization

\begin{tabular}{|l|c|c|}
\hline & Frequency & Percentage (\%) \\
\hline Strongly Agree & 36 & 72 \\
\hline Agree & 10 & 20 \\
\hline Undecided & 2 & 4 \\
\hline Disagree & 1 & 2 \\
\hline Strongly disagree & 1 & 2 \\
\hline Total & 50 & $100 \%$ \\
\hline
\end{tabular}

Table 3 shows that $72 \%$ of the respondents strongly agreed, $20 \%$ agreed, $4 \%$ were undecided, $2 \%$ disagreed, while $2 \%$ strongly disagreed. This indicates that publicity as a promotional tool promotes reputation of the firm.

Table 4. Publicity and Sales Promotion Influence Consumer Buying Decisions

\begin{tabular}{|l|c|c|}
\hline & Frequency & Percentage (\%) \\
\hline Strongly agree & 25 & 50 \\
\hline Agree & 12 & 24 \\
\hline Undecided & 5 & 10 \\
\hline Disagree & 6 & 12 \\
\hline Strongly disagree & 2 & 4 \\
\hline Total & 50 & $100 \%$ \\
\hline
\end{tabular}

Table 4 indicates that $50 \%$ of the respondents as strongly agree, $24 \%$ agreed, $10 \%$ were undecided, $12 \%$ disagreed, while $4 \%$ strongly disagreed. This indicates that publicity and sales promotion influences consumer buying decisions.

\section{Test of Hypothesis}

The formulated hypothesis is tested using the Chi-square technique.

$\mathbf{H}_{\mathbf{0}}$ : Publicity and sales promotion do not enhance firm's marketing performance in the new digital marketing era. 
$\mathbf{H}_{\mathbf{1}}$ : Publicity and sales promotion enhance firm's marketing performance in the new digital marketing era.

To test this hypothesis, the relevant questions in the questionnaire as shown in the responses in Tables 1 to 4 are polled together to actually perform the analysis. Thus, RES.1, RES.2, RES. 3 and RES. 4 in Table 5 stand for responses in Tables 1, 2,3 and 4.

Table 5. Table of Observed Frequency

\begin{tabular}{|l|c|c|c|c|c|}
\hline Responses & RES.1 & RES.2 & RES.3 & RES.4 & Total \\
\hline Strongly Agree & 44 & 40 & 36 & 25 & 145 \\
\hline Agree & 5 & 5 & 10 & 12 & 32 \\
\hline Undecided & 1 & 2 & 2 & 5 & 10 \\
\hline Disagree & 0 & 3 & 1 & 6 & 10 \\
\hline Strongly Disagree & 0 & 0 & 1 & 2 & 3 \\
\hline Total & 50 & 50 & 50 & 50 & 200 \\
\hline
\end{tabular}

To calculate Table 6, we employed the use of the Chi-square test of "independence and homogeneity" which is used once the number of rows is more than two (2). The formulae for calculating it is given as

$$
\frac{R T X C T}{G T}
$$

Table 6. Table of Expected Frequencies

\begin{tabular}{|l|c|c|c|c|}
\hline Responses & RES.1 & RES.2 & RES.3 & RES.4 \\
\hline Strongly Agree & 32.5 & 32.5 & 32.5 & 32.5 \\
\hline Agree & 8 & 8 & 8 & 8 \\
\hline Undecided & 2.5 & 2.5 & 2.5 & 2.5 \\
\hline Disagree & 2.5 & 2.5 & 2.5 & 2.5 \\
\hline $\begin{array}{l}\text { Strongly } \\
\text { Disagree }\end{array}$ & 0.75 & 0.75 & 0.75 & 0.75 \\
\hline
\end{tabular}

The formulae for computing the Chi-square is given as

$X^{2}$

$=\sum \frac{\left(0 i-E_{i}\right) 2}{E_{i}}$

where, $\chi^{2}=$ Chi- Square, $\mathrm{O}=$ Observed Value, $\mathrm{E}=$ Expected Value. The Level of Significance is taken to be $5 \%$ or confidence level of $95 \%$. With a degree of freedom of $\mathrm{DF}=\mathrm{V}=(\mathrm{R}-1)(\mathrm{C}-1)$, The $\mathrm{Chi}$ Square $\left(\mathrm{X}^{2)}\right.$ is computed as follows. 
Table 7. Chi Square $\left(X^{2}\right)$ Contingency Table

\begin{tabular}{|l|c|c|c|c|}
\hline $\mathrm{O}$ & $\mathrm{E}$ & $(\mathrm{O}-\mathrm{E})$ & $(\mathrm{O}-\mathrm{E})^{2}$ & $(\mathrm{O}-\mathrm{E})^{2} / \mathrm{E}$ \\
\hline 44 & 32.5 & 11.5 & 132.5 & 4.07 \\
\hline 5 & 8 & -3 & 9 & 1.8 \\
\hline 1 & 2.5 & -1.5 & 2.25 & 2.25 \\
\hline 0 & 2.5 & -2.5 & 6.25 & 6.25 \\
\hline 0 & 0.75 & -0.75 & 0.56 & 0.56 \\
\hline 40 & 32.5 & 7.5 & 56.25 & 1.4 \\
\hline 5 & 8 & -3 & 9 & 1.8 \\
\hline 2 & 2.5 & -0.5 & 0.25 & 0.13 \\
\hline 3 & 2.5 & 0.5 & 0.25 & 0.08 \\
\hline 0 & 0.75 & -0.75 & 0.56 & 0.56 \\
\hline 36 & 32.5 & 3.5 & 12.25 & 0.34 \\
\hline 10 & 8 & 2 & 4 & 0.4 \\
\hline 2 & 2.5 & 0.5 & 0.25 & 0.13 \\
\hline 1 & 2.5 & -1.5 & 2.25 & 2.25 \\
\hline 1 & 0.75 & 0.25 & 0.06 & 0.06 \\
\hline 25 & 32.5 & -7.5 & 56.25 & 2.25 \\
\hline 12 & 8 & 4 & 16 & 1.33 \\
\hline 5 & 2.5 & 2.5 & 6.25 & 1.25 \\
\hline 6 & 2.5 & 3.25 & 10.56 & 1.76 \\
\hline 2 & 0.75 & 1.25 & 1.56 & 0.78 \\
\hline Total & & & & 29.45 \\
\hline
\end{tabular}

$\mathrm{X}_{2} \mathrm{cal}=29.45$

To determine the table value $\left(\mathrm{X}^{2}\right.$ tab); $\mathrm{DF}=(\mathrm{R}-1)(\mathrm{C}-1)=(5-1)(4-1)=(4)(3)$ $=12$

The critical value $\mathrm{X}^{2}$ with D.F $=12$ at 0.05 level of significance is 21.03.

Decision Rule: Accept $\mathrm{H}_{0}$ if Chi Square calculated $\left(\mathrm{X}^{2}\right.$ cal) is less than $(<)$ Chi Square tabulated $\left(\mathrm{X}^{2} \mathrm{tab}\right)$, otherwise don't accept.

Managerial Decision: From Table 7, $X^{2}$ cal (29.45) is greater than $X^{2}$ tab (21.03) i.e. $X^{2}$ cal (29.45) $>X^{2}$ tab (21.03). Therefore, the null hypothesis (Ho) is rejected and the alternative hypothesis (Hi) is accepted. Thus, publicity and sales promotion are veritable promotional tools for achieving corporate marketing objectives in the new digital marketing era.

The findings from the study revealed that publicity and sales promotion enhance achievement of organizational marketing goals. It was also revealed that publicity and sales promotion is a veritable tool for increasing sales volume and enhancing corporate reputation in Nigerian Breweries PLC.

\section{Conclusion and Policy Recommendations}

Based on the findings from this study, it is evident that publicity and sales promotion are panacea for enhancing, stimulating as well as arousing customers demand for the firm's product. Publicity and sales promotion foster spontaneous 
reactions and response to sales and it influences the achievement of firm's marketing performance in the new digital era particularly in our case study company-Nigerian Breweries PLC.

Based on the aforementioned, the following policy recommendations are hereby proffered. (a) Organizations should have a planned and systematic publicity and sales promotion programmes to enhance product sales performance. (b) They should set up a more and effective promotional department with experienced staff with a view to developing more promotional strategies in line with the company's objectives without compromising product quality, performance and reliability during the campaign. (c) In addition, since effective implementation of sales promotion tools lead to increase in sales volume and invariably higher profit, therefore, adequate promotional budget should be put in place by firms to enhance the achievement of marketing objectives in the digital marketing era.

\section{Acknowledgments}

The contributions, criticisms and comments of staff and students in the Department of Business Administration and other faculty members are quite appreciated during the presentation of the paper at the seminar series. The comments of Dr. Hassan and Mr Alli are appreciated in this regard.

\section{References}

Akanbi TA, Ajagbe F (2011) The impact of sales promotion activities on the patronage of Global System of Mobile Communication (GSM) service providers in Ogbomosho area, Nigeria. Journal of Communication and Culture: International Perspective 2(3): 20-29.

Alli AI (2010) Superlative marketing with simplified questions and answers. Lagos, Nigeria: Ismosharley Ventures.

Aremu MA, Lawal AZ (2012) Exploring marketing strategy as a catalyst for performance in Nigerian telecommunication industry. International Journal of Management \& Business Studies 2(4): 65-74.

Aula P, Åberg L (2013) Blistering publicities: a new challenge for organizational communication and public relations. Communication and Media Studies. Helsinki, Finland: University of Helsinki.

Bagavathi-Pillai RSN (2007) Modern marketing. Revised Edition. New Delhi: S. C and Company Ltd.

Bernays EL (1955) The theory and practice of public relations: a resume. In EL Bernays (ed.), The Engineering of Consent, 3-25. Norman, OK: University of Oklahoma Press.

Boone LE, Kurtz DLC (2002) Contemporary marketing plus. $8^{\text {th }}$ Edition. Florida, USA: Harcourt Brace College Publishers.

Brassington F, Pettitt S (2000) Principles of marketing. $2^{\text {nd }}$ Edition, Harlow Pearson Education Limited. 
Chaharsoughi AS, Yasory HT (2012) Effect of sales promotion as a tool on customer attention to purchase: a study of Auto Maker Company. African Journal of Business Management 6(5): 2007-2014.

Daramola GC, Okafor LI, Bello MA (2014) Sales promotion on consumer purchasing behavior. International Journal of Business and Marketing Management 2(1): 8-13.

Dzansi I (2016) The effectiveness of sales promotional strategies on the performance of an organization and how it communicates to the customers. Dama International Journal of Researchers (DIJR) 1(5): 12-19.

Ekankumo B, Henry BK (2011) Sales promotion strategies of financial institutions in Bayelsa State. Asian Journal of Business Management 3(3): 203-209.

Evgeny M (2011) The net delusion: the dark side of internet freedom. New York, USA: Public Affairs.

Festus W (2016) The impact of sales promotion on organizational performance: a case study of Guinness Ghana Breweries Limited. Master Thesis. Kumasi, Ashanti, Ghana: Department of Marketing and Corporate Strategy, Kwame Nkrumah University of Science and Technology.

Gbolagade A, Adesola MA, Oyewale IO (2013) Impact of marketing strategy on business performance: a study of selected small and medium enterprises (SMEs) in Oluyole Local Government, Ibadan, Nigeria. Journal of Business and Management 11(4): 2319-7668.

Jain R (2014) Main objectives of sales promotion. Retrieved from: http://www.shareyour essays.com/89470/7-main-objectives-of-sales-promotion. [Accessed 24 February 2014]

Kotler P, Keller KL (2006) Marketing management. $12^{\text {th }}$ Edition. India: Pearson Education PLC Ltd.

Mbogo PK (2013) Influence of promotion mix strategies on the growth of customers of pathologists' lancet Kenya. Research Project. Nairobi, Kenya: School of business, University of Nairobi.

Mohammed NN, Adamkolo MI (2018) Public relations and employee performance in Nigerian institutions of higher learning. Informasi 48(2): 267-279.

Musibau AA, Choi SL, Oluyinka S (2014) The impact of sales promotion and product branding on company performance: a case study of AIICO Insurance Nigerian PLC. In International Conference on Innovation, Management and Technology Research, Malaysia, 22 - 23 September, 2013. Social and Behavioural Sciences 129(2014): 164-171.

Nadeem I, Naveed A, Muhammad A, Komal J (2013) The role of sales promotion on sales volume in the context of fast moving consuming goods (FMCG) industry in Dera Ghazi Khan. International Journal of Accounting Research 1(4): 234-254.

Nour MI, Almahirah SM, Said MS, Freihat S (2014) The impact of promotional mix elements on consumers purchasing decisions. International Business and Management 8(2): 143-151.

Odunlami IB, Ogunsiji A (2011) Effect of sales promotion as a tool on organizational performance. Journal of Emerging Trends in Economics and Management Science (JETEMS) 2(1): 9-13.

Oladele O (2006) Marketing management. Revised Edition. Lagos, Nigeria: Niyak Print and Publications.

Olawore OP (2013) Effect of sales promotion on the buying behaviour of consumers: evidence from telecommunication industry in Nigeria. Yaba Journal of Management Studies 8(1): 127-131.

Onu AJC (2000) Marketing today. Abuja, Nigeria: Precious Treasure Ltd. 
Onyejiaku CC, Ghasi NC, Okwor H (2018) Does promotional strategy affect sales growth of manufacturing firms in south east Nigeria? European Journal of Management and Marketing Studies 3(1): 43-59.

Oyedapo WO, Akinlabi BH, Sufian JB (2012) The impact of sales promotion on organization effectiveness in Nigeria manufacturing industry. Universal Journal of Marketing and Business Research 14(Oct): 128-131.

Oyeniyi O (2011) Sales promotion and consumer loyalty. A study of Nigerian telecommunication industry. Journal of Competitiveness 4(Jan): 66-67.

Pandey R, Singh N (2017) Role of public relations in image management of an organization. International Journal of Advance Research, Ideas and Innovations in Technology 3(4): 164-168.

Pembi S, Fudamu UA, Adamu I (2017) Impact of sales promotional strategies on organizational performance in Nigeria. European Journal of Research and Reflection in Management Sciences 5(4): 31-42.

Preko A (2012) The effect of sales promotion on television advertising revenue: a study of TV Africa, Ghana. Journal of Emerging Trends in Economics and Management Sciences (JETEMS) 3(2): 141-146.

Sadia M, Syeda NZR (2012) Impact of sales promotion on organizations' profitability and consumer's perception in Pakistan. Interdisciplinary Journal of Contemporary Research in Business 3(5): 14-16.

Salaam T (2017) Effect of marketing communication mix on sales performance of soft drink companies in Dares. Master Thesis. Kenya: School of Business, Kenyatta University.

Tandoh I, Sarpong L (2015) The impact of sales promotions on the performance of automobile industries in Ghana: a study of PHC motors (Accra-Ghana). European Journal of Business and Management 7(11): 176-184.

Tarlow PE (2011) Tourism risk management in an age of terrorism. Economic Autonoma Journal 2(7): 1-13.

Tufail S, Saeed R, Zameer H, Bilal M, Naeem B (2014) Impact of sponsorship and publicity on brand equity. International Journal of Academic Research in Business and Social Sciences 4(11): 15-23.

Zeng B (2013) Social media in tourism. The Journal of Tourism Hospitality 2(2): 125126. 
